\title{
Phytoextraction of Heavy Metals and Risk Associated with Vegetables Grown from Soil Irrigated with Refinery Wastewater
}

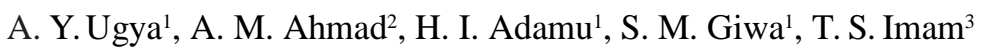 \\ ${ }^{1}$ Department of Environmental Management, Kaduna State University, Kaduna, Nigeria. \\ ${ }^{2}$ Department of Biochemistry, Kaduna State University, Kaduna, Nigeria. \\ ${ }^{3}$ Department of Biological Sciences, Bayero University Kano, Kano, Nigeria.
}

\begin{tabular}{|c|c|}
\hline ARTICLE INFO & ABSTRACT \\
\hline $\begin{array}{l}\text { Article history: } \\
\text { Received on: May 27, } 2018 \\
\text { Accepted on: July 08, } 2018 \\
\text { Available online: March 05, } 2019\end{array}$ & $\begin{array}{l}\text { With the increase in anthropogenic activities, Heavy metal contamination of vegetables is inevitable as such } \\
\text { it has become a course for concern due to food safety issues and potential health risk. This research is aimed } \\
\text { at evaluating the phytoextraction efficiency of some vegetables and the potential health risk resulting fromthe } \\
\text { consumption of vegetables that are grown in agricultural soil irrigated with Refinery wastewater. Wastewater } \\
\text { was collected from the effluent point of Kaduna Refining and Petrochemical Company from October } 2016\end{array}$ \\
\hline $\begin{array}{l}\text { Key words: Bioaccumulation, } \\
\text { Biomagnification, } \\
\text { Phytoextraction, Food Chain. }\end{array}$ & 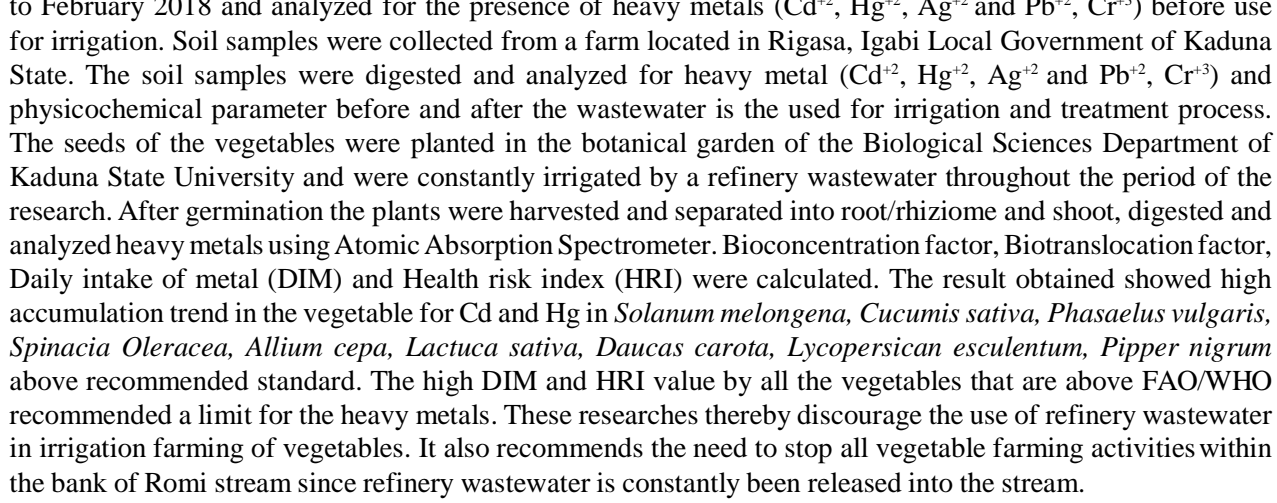 \\
\hline
\end{tabular}

\section{INTRODUCTION}

Industrial and sewage wastewater are continuously disposed of in open drains whose water is used for irrigation $[1,2]$. These wastewaters contains huge amount of heavy metals e.g. iron (Fe), manganese $(\mathrm{Mn})$, lead $(\mathrm{Pb})$, copper $(\mathrm{Cu})$, zinc $(\mathrm{Zn})$, chromium $(\mathrm{Cr})$, cobalt $(\mathrm{Co})$, nickel $(\mathrm{Ni})$, and cadmium $(\mathrm{Cd})$ along with organic matter and nutrients. Crops irrigated by wastewaters store and secrete these heavy metals through various parts. These heavy metals cause serious health effects when consumed through foods $[1,6]$. Many clean-up technologies exist for the treatment of contaminated soils, but only a few are applicable to heavy metal contaminated soils. The use of plants and associated

"Corresponding Author

A. Y. Ugya, Department of Environmental Management, Kaduna State University, Kaduna, Nigeria.E-mail: ugya88 @ kasu.edu.ng microorganisms to contain, inactivate, remove or degrade harmful environmental contaminants and to revitalize contaminated sites is gaining more and more attention [3]. Plants and leafy vegetables have a high capacity to bioaccumulate these heavy metals when grown in soil irrigated by wastewater $[4,5,6]$ Irrigation can impact potential yield by affecting morphological and physiological traits. Irrigation of crops by wastewater for a long period of time causes increased concentration of heavy metals in plants and vegetables through bioaccumulation $[7,8]$. Heavy metals accumulate in all parts of vegetables with only a few eg $\mathrm{Zn}, \mathrm{Ni}, \mathrm{Cu}$ that are essential for body function at low concentration, $\mathrm{Zn}$ at high concentrations causes abnormal functions of reproductive activities $[8,9,10,11]$. Vegetables constitute an important part of the human diet since they contain carbohydrates, proteins, as well as vitamins, minerals and also a source of micro and macro elements. Heavy metals are one of a range of important types of contaminants that can be found on the surface and in the tissue of fresh vegetables 
[12,13]. A number of elements, such $\mathrm{Pb}, \mathrm{Cd}, \mathrm{Ni}, \mathrm{Co}, \mathrm{Cr}, \mathrm{Cu}$ and Selenium (Se) can be harmful to plants and humans even at quite low concentrations $[14,15,16]$.

Soil pollution is caused by misuse of the soil, such as poor agricultural practices, disposal of industrial and urban wastes, etc. The soil is also polluted through the application of chemical fertilizers (like phosphate and Zn fertilizers), and herbicides [17,18,19]. Heavy metal accumulation in soils is of concern in agricultural production due to the adverse effects on food quality, crop growth, and environmental health. Plant species have varying capacities of removing and bioaccumulating heavy metals. Researches have shown that some plant species selectively bioaccumulate heavy metals [21,22,23]. Vegetables, especially leafy vegetables, bioaccumulate higher amounts of heavy metals [23]. Roots and leaves of herbaceous plants retain a higher concentration of heavy metal than stems and fruits [12]. There are limited studies on heavy metal content at different growth stages of vegetables, available studies focused on the status of metal content inedible parts of vegetables [15]. A review of the literature also showed the scarcity of data on the comparison of metal content on different leafy vegetable species in Hawul [15]. Potentially harmful metal contents in soils may come not only from the bedrock itself, but also from anthropogenic sources like solid or liquid waste deposits, agricultural inputs, and the fallout of industrial and urban emissions [24]. Excessive accumulation in agricultural soils may result not only in soil contamination but has also had consequences on food quality and safety. So, it is essential to monitor food quality, given that plant uptake is one of the main pathways through which heavy metals (HMs) nter the food chain [25]. Vegetables are very important because they contain essential components of protein, vitamins, iron, calcium and other nutrients $[26,27]$. However, their nutritional value and consumer acceptance as food must be taken into consideration, because vegetables can contain both essential and non-essential elements over a wide range of concentrations $[28,29]$. It is well established that the daily intake of heavy metal contaminated vegetables may pose a risk to human health. This is because heavy metals can bioaccumulate in living organisms and at elevated levels, they can be toxic. It has been reported that prolonged consumption of unsafe concentrations of heavy metals through foodstuffs may lead to the chronic accumulation of metals in the kidney and liver of humans, causing disruption of numerous biochemical processes, leading to cardiovascular, nervous, kidney, and bone diseases [31,32,33]. Absorption and accumulation of heavy metals in vegetables and fruits are influenced by many factors, such as their solubility, soil $\mathrm{pH}$, plant species; soil type, the concentration of heavy metals in soil, composition, and intensity of atmospheric deposition, including precipitations, the phase of plant vegetation [21,34]. To all of these, can be added other sources generated by agricultural technologies such as irrigation with wastewater, the administration of organic and mineral fertilizers with a load of heavy metals, or application of pesticides, which contain in their structure as chemical elements [35]. Urban, industrial, household activities and traffic contribute significantly to increasing the load degree of heavy metals containing particles of inferior atmosphere [34]. The intake of heavy metals can lead to altering of humans and animals state of health. Thus, the carcinogenic effects generated by the continuous consumption of fruits and vegetables loaded with heavy metals such as $\mathrm{Cd}, \mathrm{Pb}$ or even $\mathrm{Cu}$ and $\mathrm{Zn}$ are known. There are already published works related to the incidence of gastrointestinal cancer, cancer of the pancreas, urinary bladder or prostate $[1,28]$. In Romania, there are three areas (CopşaMică-Sibiu County, Zlatna - Alba County and Baia Mare - Maramures County) that are strongly polluted with heavy metals, caused by nonferrous ores extraction and metallurgical processing. The concentrations of heavy metals in the soils around these localities are higher than the maximum allowable limits. As a result, the plants, including vegetables, bioaccumulated high quantities of such chemical elements $[14,15]$. Human exposures to heavy metals may occur through inhalation of air or ingestion of food and water. Heavy metals concentration in the environment varies markedly depending on their concentrations in soil and vicinity to sources of emission [36,37]. Heavy metal accumulation in soil and plants is of increasing concern because of the potential human health risk. Food chain contamination is one of the most important pathways for the entry of these toxic elements into the human body. Phytoremediation, also known as green technology, which consists of the use of plants including trees, grasses, herbs and aquatic plants to extract, sequester, and detoxify heavy metals, is a novel approach that has shown considerable promise as a costeffective and an environmentally friendly technology and has received much attention in recent years $[40,41,42]$. In this technique, the natural capacity of plants is used to extract some elements and compounds from soil and translocate them between fruits, flowers, leaves, stems, and roots relating to the biological stage in which the elements and compounds are involved [43,44]. Phytoremediation of heavy metals is divided into three categories: phytoextraction, which shows theability of plants to extract heavy metals from soil by accumulating the metal in aerial parts of plant $[45,46,47]$; phytostabilization, which is the use of plants to stabilize the soil surface by maintaining the metals in the roots $[48,49]$; and rhizofiltration, which is the use of plant roots to ab/adsorb metals from water and aqueous waste streams [50,51]. This research thereby determine the phytoextraction efficiency and the risk associated with vegetables grown from soil irrigated with wastewater from refinery since this wastewater is used for vegetable farming at the bark of Romi stream and River Kaduna when it finally makes it way into this stream and river respectively.

\section{MATERIAL AND METHODS}

\subsection{Water Sampling and Analysis}

Wastewater was collected from effluent point discharge of Kaduna Refining and Petrochemical Company from October 2016 to February 2018 and transported to the laboratory for analysis of heavy metals $\left(\mathrm{Cd}^{+2}, \mathrm{Hg}^{+2}, \mathrm{Ag}^{+2}\right.$ and $\left.\mathrm{Pb}^{+2}, \mathrm{Cr}^{+3}\right)$ before used for irrigation.

\subsection{Soil Collection and Analysis}

Soil samples were collected from a farm located in Rigasa, Igabi Local Government of Kaduna State. The samples were collected from this location because it is an area of minimal anthropogenic activities such as industrial, artisanal or water body for irrigation that can lead to heavy metal pollution. Surface soil $(0-20 \mathrm{~cm})$ samples were collected using a stainless steel grab sampler. The sampler was inspected for possible cross-contamination and cleaned with ambient water for individual sample collection. The soil was sampled from the central part of the grab sampler by avoiding contact with the inside materials of the sampler and transferred to a pre-cleaned plastic container [52]. The surface soil samples were collected in pre-cleaned zipper polythene bags, which were kept in airtight large plastic containers [53]. Soil samples were air-dried, grounded into fine powder and passed through 2-mm mesh sieve and stored at ambient temperature prior to analysis. The soil samples were digested and analyzed for heavy metal $\left(\mathrm{Cd}^{+2}\right.$, $\mathrm{Hg}^{+2}, \mathrm{Ag}^{+2}$ and $\left.\mathrm{Pb}^{+2}, \mathrm{Cr}^{+3}\right)$ and physicochemical parameter using the method employed by Yoon et al. [55] before and after the wastewater is used for irrigation and treatment process. 


\subsection{Plants Collection and Identification}

The seed of the vegetables (Table 2) used for this research was purchase in Bakin-Dogo market located in Kaduna south local government, Kaduna, Nigeria.

Table 1: Plants used for Phytoextraction

\begin{tabular}{ccc} 
SN & Scientific Name & Common Name \\
$\mathbf{1}$ & Allium cepa & Onion \\
$\mathbf{2}$ & Cucumis sativa & Cucumber \\
$\mathbf{3}$ & Lactuca sativa & Lettuce \\
$\mathbf{4}$ & Daucas carota & Carrot \\
$\mathbf{5}$ & Lycopersican esculentum & Tomato \\
$\mathbf{6}$ & Spinacia Oleracea & Spinach \\
$\mathbf{7}$ & Solanum melongena & Garden egg \\
$\mathbf{8}$ & Pipper nigrum & Pepper \\
$\mathbf{9}$ & Phasaelus vulgaris & Green beans \\
\hline
\end{tabular}

Table 2: Biotranslocation Factor of Vegetables Irrigated with Refinery Wastewater.

\begin{tabular}{ccccccc}
$\mathbf{S N}$ & Plant Sample & $\mathbf{C d}$ & $\mathbf{H g}$ & $\mathbf{A g}$ & $\mathbf{P b}$ & $\mathbf{C r}$ \\
$\mathbf{1}$ & Allium cepa & 1.3 & 1.1 & 0.1 & 0.4 & 0.3 \\
$\mathbf{2}$ & Cucumis sativa & 3.8 & 1.5 & 0.6 & 2.3 & 1.2 \\
$\mathbf{3}$ & Lactuca sativa & 2.5 & 0.1 & 0.1 & 0.1 & 1.3 \\
$\mathbf{4}$ & Daucas carota & 2.2 & 0.1 & 0.1 & 0.2 & 0.5 \\
$\mathbf{5}$ & Lycopersican esculentum & 1.3 & 0.2 & 0.6 & 0.8 & 0.4 \\
$\mathbf{6}$ & Spinacia Oleracea & 1.7 & 1.4 & 0.7 & 0.3 & 0.2 \\
$\mathbf{7}$ & Solanum melongena & 4.8 & 2.0 & 2.4 & 1.6 & 2.1 \\
$\mathbf{8}$ & Pipper nigrum & 1.6 & 1.5 & 1.3 & 1.8 & 2.0 \\
$\mathbf{9}$ & Phasaelus vulgaris & 3.3 & 1.8 & 2.1 & 2.5 & 1.9 \\
\hline
\end{tabular}

\subsection{Experimental Setup}

The purchase seeds were planted in the botanical garden of the Biological Sciences Department of Kaduna State University and constantly irrigated by refinery wastewater throughout the period of the research. After germination, the plants were harvested and separated into root/rhiziome and shoot, the root/rhiziome and shoot. The separated plant parts were digested and heavy metals analysis was carried out using AAS. Bioconcentration factor and Bio translocation factor were thus calculated using the method of Ugya et al. [55], Daily intake of metal (DIM) and Health risk index (HRI) was calculated according to Khan et al. (2013) [58].

\section{RESULT AND DISCUSSION}

The bioaccumulation and translocation abilities of the plant species varies by species of plant and irrigation source. It was reported that the accumulation of metal by a plant depends on factors such as physicochemical parameters of soil (Table 6), the plant species involved, climatic condition and speciation of metal [57,58,59]. The heavy metals content of the soil generally changes with irrigation of the soil with refinery wastewater and this had led to the accumulation of the heavy metal in the edible part of the vegetables which is detrimental to human health $[60,61]$. The accumulation trend in the vegetable for $\mathrm{Cd}$ and $\mathrm{Hg}$ is Solanum melongena $>$ Cucumis sativa $>$ Phasaelus vulgaris $>$ Spinacia Oleracea > Allium cepa > Lactuca sativa > Daucas carota > Lycopersican esculentum > Pipper nigrum although the studies show a significant difference in the BTF and BCF of $\mathrm{Cd}$ and $\mathrm{Hg}$ when the vegetables were irrigated Refinery water. The result show higher BTF and BCF by Solanum melongena, followed by Cucumis sativa and Phasaelus vulgaris signifying that these three vegetables are best in phytoextraction of $\mathrm{Cd} \mathrm{Hg}$ than the other vegetables $[63,64,65]$. The result also show higher BTF and BCF by Phasaelus vulgaris followed by Cucumis sativa and Solanum melongena signifying that these three vegetables are best in phytoextraction of $\mathrm{Ag}, \mathrm{Pb}$, and $\mathrm{Cr}$ than the other vegetables $[65,66,67]$. The studied data showed that the heavy metals content varies among different vegetables. The variations in heavy metals concentrations in vegetables may be ascribed to the differences in their morphology and physiology for heavy metals uptake, exclusion, accumulation and retention $[68,69,70]$. The result obtained also show high DIM and HRI value by all the vegetables that are above FAO/WHO recommended a limit for the heavy metals (Tables 4 and 5). The estimation of the risk to human health from the presence of heavy metals in food, particularly in vegetables, according to the European Food Safety Authority (EFSA) is between $0.3 \mathrm{mg} / \mathrm{kg}$ b.w. per day for heavy metals from the lowest Non-Observed Adverse Effect Level (NOAEL) identified in a (National Toxicology Program) NTP chronic oral toxicity study in rats [71]. The presence of these metals into the food chain may either in the long run or short span affect human health and creates toxicity which can result in nausea, vomiting, abdominal pains, anorexia, constipation, insomnia, anemia, irritability, mood disturbances, coordination loss and neurological effect $[71,72,64]$. In the consumption habits of local residents, the leafy vegetable consumption accounted for $70 \%$ of total consumption of vegetables, while other vegetables amount to $30 \%[73,70]$. Chronic low-level intake of toxic metal elements has a negative effect on human health, and the detrimental impact becomes apparent after several years of exposure $[74,75]$.

Table 3: Mean Bioconcentration Factor of Vegetables Irrigated with Refinery Wastewater.

\begin{tabular}{ccccccc} 
SN & Plant Sample & Cd & Hg & Ag & Pb & Cr \\
$\mathbf{1}$ & Allium cepa & 0.5 & 0.6 & 0.7 & 0.7 & 0.5 \\
$\mathbf{2}$ & Cucumis sativa & 2.0 & 1.9 & 1.9 & 1.8 & 2.1 \\
$\mathbf{3}$ & Lactuca sativa & 0.5 & 0.2 & 0.5 & 0.3 & 0.2 \\
$\mathbf{4}$ & Daucas carota & 0.7 & 0.3 & 0.3 & 0.3 & 0.9 \\
$\mathbf{5}$ & Lycopersican esculentum & 0.4 & 0.7 & 1.1 & 1.1 & 1.3 \\
$\mathbf{6}$ & Spinacia Oleracea & 1.6 & 1.8 & 1.7 & 0.6 & 0.5 \\
$\mathbf{7}$ & Solanum melongena & 2.0 & 2.7 & 1.8 & 1.6 & 1.5 \\
$\mathbf{8}$ & Pipper nigrum & 1.7 & 1.7 & 1.5 & 2.0 & 1.3 \\
$\mathbf{9}$ & Phasaelus vulgaris & 1.8 & 2.0 & 2.3 & 2.7 & 2.6 \\
\hline
\end{tabular}

Table 4: Mean Health risk index (HRI) arising out of consumption of vegetables irrigated with Refinery Wastewater.

\begin{tabular}{ccccccc}
$\mathbf{S N}$ & Plant Sample & $\mathbf{C d}$ & $\mathbf{H g}$ & $\mathbf{A g}$ & $\mathbf{P b}$ & $\mathbf{C r}$ \\
$\mathbf{1}$ & Allium cepa & 1.4 & 0.5 & 0.6 & 1.5 & 0.6 \\
$\mathbf{2}$ & Cucumis sativa & 0.6 & 0.6 & 0.5 & 0.5 & 1.5 \\
$\mathbf{3}$ & Lactuca sativa & 0.5 & 0.7 & 0.8 & 0.7 & 0.5 \\
$\mathbf{4}$ & Daucas carota & 0.7 & 0.6 & 0.6 & 0.8 & 0.9 \\
$\mathbf{5}$ & Lycopersican esculentum & 1.5 & 0.9 & 0.6 & 0.5 & 1.4 \\
$\mathbf{6}$ & Spinacia Oleracea & 0.7 & 0.8 & 0.7 & 0.9 & 0.8 \\
$\mathbf{7}$ & Solanum melongena & 0.5 & 1.1 & 1.5 & 0.6 & 0.6 \\
$\mathbf{8}$ & Pipper nigrum & 0.6 & 0.5 & 0.8 & 0.6 & 1.5 \\
$\mathbf{9}$ & Phasaelus vulgaris & 0.6 & 0.5 & 0.9 & 0.5 & 0.6 \\
\hline
\end{tabular}


Table 5: Daily Intake of Heavy Metals (DIM) (mg/kg bw/day) arising out of consumption of vegetables irrigated with Refinery Wastewater.

\begin{tabular}{ccccccc}
$\mathbf{S N}$ & Plant Sample & $\mathbf{C d}$ & $\mathbf{H g}$ & $\mathbf{A g}$ & $\mathbf{P b}$ & $\mathbf{C r}$ \\
$\mathbf{1}$ & Allium cepa & 1.5 & 0.8 & 0.6 & 0.7 & 1.4 \\
$\mathbf{2}$ & Cucumis sativa & 0.7 & 0.5 & 0.6 & 0.8 & 0.6 \\
$\mathbf{3}$ & Lactuca sativa & 0.5 & 0.5 & 0.7 & 0.7 & 0.8 \\
$\mathbf{4}$ & Daucas carota & 0.6 & 0.7 & 0.5 & 0.8 & 0.7 \\
$\mathbf{5}$ & Lycopersican esculentum & 0.5 & 0.5 & 0.7 & 0.6 & 1.4 \\
$\mathbf{6}$ & Spinacia Oleracea & 0.5 & 0.7 & 0.6 & 0.6 & 0.9 \\
$\mathbf{7}$ & Solanum melongena & 1.4 & 0.7 & 0.6 & 0.6 & 0.6 \\
$\mathbf{8}$ & Pipper nigrum & 0.7 & 0.4 & 0.6 & 0.8 & 0.8 \\
$\mathbf{9}$ & Phasaelus vulgaris & 0.6 & 0.6 & 0.7 & 0.8 & 0.9 \\
\hline
\end{tabular}

Table 6: Physico-chemical Parameter of Soil Sample.

\begin{tabular}{cccc} 
SN & $\begin{array}{c}\text { Physico-chemical } \\
\text { Parameter }\end{array}$ & $\begin{array}{c}\text { Quality/Concentration } \\
\text { Before Treatment }\end{array}$ & $\begin{array}{c}\text { Quality/Concentration } \\
\text { After Treatment }\end{array}$ \\
\hline 1 & Soil Type & Sandy loamy & Sandy loamy \\
2 & Total Nitrogen & $350.98 \mathrm{mg} / \mathrm{kg}$ & $150.13 \mathrm{mg} / \mathrm{kg}$ \\
3 & Phosphorus & 5.78 & 2.13 \\
4 & PH & 5.31 & 6.91 \\
5 & Electrical Conductivity & $6.75 \mathrm{Ms} / \mathrm{cm}$ & $2.04 \mathrm{Ms} / \mathrm{cm}$ \\
6 & Organic Carbon & $1.08 \%$ & $1 \%$ \\
\hline
\end{tabular}

\section{CONCLUSION}

Since heavy metals tend to have an identical tendency to be phytoaccumulation, with Bioconcentration higher than biotranslocation [77], these research have also shown the ability of Solanum melongena, Cucumis sativa, Phasaelus vulgaris, Spinacia Oleracea, Allium cepa, Lactuca sativa, Daucas carota, Lycopersican esculentum, Pipper nigrum to phytoaccumulate significant amounts of these toxic metals. Many researchers such as Ugya et al. [55], Ugya et al. [77] have shown the presence of these heavy metals in Kaduna Refining and Petrochemical Company wastewater and Romi stream which causes cross-contamination of the food chain [77]. The ability of Solanum melongena, Cucumis sativa, Phasaelus vulgaris, Spinacia Oleracea, Allium cepa, Lactuca sativa, Daucas carota, Lycopersican esculentum, Pipper nigrum to bioremediate this water pollution is a promising technology which will easily serve as an alternative method of remediation compared to another convectional method. These researches validate the consumption of these vegetables as not totally safe since it could biomagnify in the food chain. These researches thereby discourage the use of refinery wastewater in irrigation farming of vegetables. It also recommends the need to stop all vegetable farming activities within the bank of Romi stream since refinery wastewater is constantly been released into the stream.

\section{REFERENCES}

1. Sharma A, Katnoria JK, Nagpal AK. Heavy metals in Vegetables: Screening Health Risks involved in Cultivation along Wastewater Drain and Irrigrating with Wastewater. Springplus 2016;5:488.

2. Su C, Jiang LQ, Zhang WJ. A review on heavy metal contamination in the soil worldwide: situation, impact and remediation techniques. Environmental Skeptics and Critics 2014; 3(2):24-38.

3. Vaikosen EN, Alade GO. Determination of heavy metals in medicinal plants from the wild and cultivated garden in Wilberforce Island, Niger
Delta region, Nigeria Journal of Pharmacy \& Pharmacognosy Research 2017; 5 (2):129-143.

4. Li B, Wang Y, Jiang Y, Li G, Cui J, Wang Y, Zhang H, Wang S, Xu $S$, Wang R. The accumulation and health risk of heavy metals in vegetables around a zinc smelter in northeastern China. Environ Sci Pollut Res 2016

5. Ugya AY, Imam TS, Agamuthu P. The effect of heavy metal air pollution arising from local metallurgical activities on albino rat. AM J Med Public Health 2017; 1(1):10-19.

6. Ugya AY, Imam TS. Temporal heavy metals variation in vegetables sampled at kasuwan mata, kaduna metropolis, Nigeria. Malaysian Journal of Science 2017; 36(2):63-73.

7. Rana MK, Farooq A, Adnan SA, Osama SK, Abdul W, Muhammad F, Maqsood A. Assessment of Heavy Metals in Vegetables Cultivated in Land Irrigated from Hudiara Drain. JECET 2014; 3(3):1218-1227.

8. Pan X, Wu P, Jiang X. Level and Potential Health Risk of Heavy Metals in Marketed Vegetablres in Zhenjiang China. Scientific Report 2016; 6(20317).

9. Siegel KR, Ali MK, Srinivasiah A, Nugent RA, Narayan KMV. Do We Produce Enough Fruits and Vegetables to Meet Global Health Needs. Plos one 2014; e104059.

10. Zhong T, Xue D, Zhao L, Zhang X. Concentration of Heavy Metals in Vegetables and Potential Health Risk Asssessment in China. Environ Geochem Health 2017; PMID 28194624.

11. Ogunkunle CO, Ite AE, Adeniyi SA, Akintola EO, Okere UV. Urban vegetable farming: Anthropic level, bioavailability, and health implication associated with bioaccumulated trace metals in selected vegetables in Ilorin, Nigeria. Pollution 2017;3(2):285-300.

12. Mafuyai GM, Kamoh NM, Kangpe NS, Ayuba SM, Eneji IS. Heavy metals contamination in road side dust along major traffic roads in Jos metropolitan Area Nigeria. European Journal of Earth and Environment 2015; 2(1).

13. Ojo AA. Review on heavy metals contamination in the environment european journal of earth and environment 2017;4(1).

14. Usman YB, Kolo BG. Assessment of some pollutants in soils of Sakwa, Thilaand Marama in Hawul Local Government Area, Borno State, Nigeria. Ew J Anal \& Environ Chem 2015; 1(1):20-24.

15. Usman B, Kolo BG, Lawan M, Usman YB. Determination of heavy metals and ions in vegetable samples from Wawah and Yimir-dhalang agricultural areas, KwayaKusar Local Government, Borno State. Ew J Anal and Environ Chem 2015; 1(1):14-19.

16. Liu D, Li S, Islam E, Chen JR, Wu JS, Ye ZQ, Peng DL, Yan WB, Lu KP. Lead accumulation and tolerance of Moso bamboo(Phyllostachys pubescens) seedlings: applications of phytoremediation. Journal of Zhejiang University SCIENCE B16 2015; 123-130.

17. Mahmoud EK, Ghoneim AM. Effect of polluted water on soil and plant contamination by heavy metals in El-Mahla El-Kobra, Egypt. Solid Earth 2016; 7:703-711.

18. Li L, Hu T, Li X, Mu S, Cheng Z, Ge W, Gao J. Genome-wide analysis of shoot growth-associated alternative splicing in moso bamboo. Molecular Genetics and Genomics 2016;291:1695-1714.

19. Li Q, Song X, Gu H, Gao F. Nitrogen deposition and management practices increase soil microbial biomass carbon but decrease diversity in Moso bamboo plantations. Nature Scientific Reports. 2016; 6:28235.

20. Shen X, Huang DY, Ren XF, Zhu HH, Wang S, Xu C, He YB, Luo $\mathrm{ZC}$, Zhu QH. Phytoavailability of $\mathrm{Cd}$ and $\mathrm{Pb}$ in crop straw biocharamended soil is related to the heavy metal content of both biochar and soil. Journal of Environmental Management 2016;168:245-251.

21. Sultana MS, Rana S, Yamazaki S, Aono T, Yoshida S. Health risks assessment of carcinogenic and non carcinogenic heavy metal exposure from vegetables and fruits of Bangladesh. Cogent Environmental Sciences 2017; 3:1291107.

22. Micheal B, Patrick O, Vivian T. Cancer and noncancer risks associated with heavy metal exposures from street foods: Evaluation of roasted meats in an urban setting. Journal of Environment Pollution and Human Health $2015 ; 3: 24-30$. 
23. Ogwokan P, Bamuwamye M, Apili G, Musalima JH. Health risk posed by lead, copper and iron via consumption of organ meats in Kampala City (Uganda). Journal of Environment pollution and human health 2014; 2:69-73.

24. Yu X, Wang Z, Lynn A, Cai J, Huangfu Y. Heavy Metals in Wheat Grown in Sewage Irrigation: A Distribution and Prediction Model. Polish Journal of Environment Studies 2016;25:413-419.

25. Hu B, Zhou J, Liu L, Meng W, Wang Z. Assessment of Heavy Metal Pollution and Potential Ecological Risk in Soils of Tianjin Sewage Irrigation Region, North China. J Environ Anal Toxicol 2017; 7:1.

26. Bahemuka TE, Mubofu EB. Heavy metals in edible green vegetables grown along the sites of the Sinza and Msimbazi rivers in Dar es Salaam, Tanzania. Food Chem 2015; 66(1):63-6.

27. Chien LC, Hung TC, Choang KY, Yeh CY, Meng PJ, Shieh MJ, Han BC. Daily intake of TBT, Cu, Zn, Cd and As for fishermen in Taiwan. Sci Total Environ 2015; (1-3):177-85.

28. Gupta N, Khan DK, Santra SC. An assessment of heavy metal contamination in vegetables grown in wastewater-irrigated areas of Titagarh, West Bengal, India. Bull Environ ContamToxicol 2017; 80(2):115-8.

29. Ugya AY, Ahmad AM. The significance of Refinery Effluent Remediation in the Conservation of Aquatic Ecosystem. Biodiversity Conservation in Changing Climate, First edited by Dr M.M Abid Ali Khan, Murtaza Abid, Prof. M.S Naqvi, Dr. Abideen Mustafa Omer, Dr B. Rani, Dr. S.N Haider, chapter 16; Publisher: Lenin Media Private Limited, Delhi, India. 2016.

30. Wang C, Chen Y, Liu J, Wang J, Li X, Zhang Y, Liu Y. Health risks of thallium in contaminated arable soils and food crops irrigated with wastewater from a sulfuric acid plant in western Guangdong province, China. Ecotoxicology and Environmental Safety 2013;90:76-81.

31. Mahmood A, Malik RN. Human health risk assessment of heavy metals via consumption of contaminated vegetables collected from different irrigation sources in Lahore, Pakistan. Arabian Journal of Chemistry 2014; 7:91-99.

32. Islam M, Rahman S, Ahmed S, Haque M. Biochemical characteristics and accumulation of heavy metals in fishes, water and sediments of the river Buriganga and Shitalakhya of Bangaldesh. Journal of Asian Scientific Research 2014; 4(6):270-279.

33. Pan X, Wu P, Jiang X. Level and Potential Health Risk of Heavy Metals in Marketed Vegetablres in Zhenjiang China. Scientific Report 2016; 6(20317).

34. Musilova J, Bystricka J, Vollmannova A, Janotova B, Orsak M, Harangozo L, Hegedusova A. Safety of Potato Copnsumption in Slovak Region Contaminated by Heavy Metals due to Previous Mining Activities. Journal of Food Quality 2017; Article ID: 9385716.

35. Danaher JJ, Pickens JM, Sibley JL. Tomato seedling growth response to different water sources and a substrate partially replaced with dewatered aquaculture effluent. Int J Recycle Org Waste Agricult 2016; 5:25.

36. Embrandiri A. Effects of oil palm decanter cake on growth of selected vegetables. $\mathrm{PhD}$ thesis, Universiti Sains Malaysia. 2016.

37. Zhou H, Zeng M, Zhou X, Liao BH, Peng PQ, Hu M, Zhu W, Wu YJ, Zou ZJ. Heavy metal translocation and accumulation in iron plaques and plant tissues for 32 hybrid rice (Oryza sativa L.) cultivars. Plant Soil 2015; 386, 317-329.

38. Barone G, Storelli A, Garofalo R, Busco VP, Quaglia NC, Centrone G, Storelli MM. Assessment of mercury and cadmium via seafood consumption in Italy: Estimated dietary intake (EWI) and target hazard quotient (THQ). Food Addit Contam A 2015; 32:1277-1286.

39. Zhou H, Zeng M, Zhou X, Liao BH, Peng PQ, Hu M, Zhu W, Wu YJ, Zou ZJ. Heavy metal translocation and accumulation in iron plaques and plant tissues for 32 hybrid rice (Oryza sativa L.) cultivars. Plant Soil 2015; 386:317-329.

40. Ugya AY, Imam TS, Tahir SM. The Role of Phytoremediation in Remediation of Industrial Waste. World Journal of Pharmaceutical Sciences 2016; 5(12):1403-1430.

41. Ugya AY, The efficiency of Lemna minor L. in the phytoremediation of Romi stream: A case study of Kaduna refinery and petrochemical company polluted stream. J Applied Biol Biotechnol 2015; 3:11-14.

42. Jena V, Dixit S, Gupta S. Risk assessment of heavy metal toxicity through edible vegetables from industrial area of Chhattisgarh. International Journal of Environmental Science and Technology 2012; 2(4):124-127.

43. Jolly Y, Islam A, Akbar S. Transfer of metals from soil to vegetables and possible health risk assessment. Springer Plus 2013; 2(1):385.

44. Kumar V, Chopra AK. Effects of sugarcane pressmud on agronomical characteristics of hybrid cultivar of eggplant (Solanum melongena L.) under field conditions. Int J Recycle Org Waste Agricult 2016; 5:149.

45. Liew WL, Kassim MA, Muda K, Loh SK, Affam AC. Conventional methods and emerging wastewater polishing technologies for palmoil mill effluent treatment: a review. J Environ Manag 2015; 149:222-235.

46. Ndaeyo NU, Ikeh AO NK, Akpan EA, Udoh EI. Growth and foliar yield responses of waterleaf (Talinum triangulare Jacq) to complementary application of organic and inorganic fertilizers in a ultisol. Am J Exp Agricult 2013; 3(2):324-335.

47. Narsimha A, Narshimha CH, Srinivasulu P, Sudarshan V. Relating apparent electrical conductivity and $\mathrm{pH}$ to soil and water in Kanagal surrounding area, Nalgonda district, Andhra Pradesh. Der Chemica Sinica 2013; 4(2):25-31.

48. Dong Z, Bank MS, Spengler JD. Assessing Metal Exposures in a Community near a Cement Plant in the Northeast US. Int J Environ Res Public Health 2015; 12:952-969.

49. Mahmood A, Malik RN. Human health risk assessment of heavy metals via consumption of contaminated vegetables collected from different irrigation sources in Lahore, Pakistan. Arabian Journal of Chemistry 2014; 7:91-99.

50. Song X, Gu H, Wang M, Zhou G, Li Q. Management practices regulate the response of Moso bamboo foliar stoichiometry to nitrogen deposition. Scientific Reports 2016; 6:24107.

51. Allen SE, Grim HM, Rowland AP. 1986. Chemical analysis. In: Moore PD, Chapman SB (eds). Methods in plant ecology. Oxford: Blackwell Scientific Publication 285-344.

52. Rahman SH, Khanam D, Adyel TM, Islam MS, Ahsan MA, Akbor MA. Assessment of Heavy Metal Contamination of Agricultural Soil around Dhaka Export Processing Zone (DEPZ), Bangladesh: Implication of Seasonal Variation and Indices. Applied Science 2012; 2:584-601.

53. Iqbal J, Shah MH. Distribution, correlation and risk assessment of selected metals in urban soils from Islamabad, Pakistan. Journal of Hazardous Materials 2011; 192:887-898.

54. Yoon J, Cao X, Zhou Q, Ma LQ. Accumulation of $\mathrm{Pb}, \mathrm{Cu}$, and $\mathrm{Zn}$ in native plants growing on a contaminated Florida site. Sci Total Environ 2006; 368:456-464.

55. Ugya AY, SM Tahir, TS Imam. The efficiency of Pistia stratiotes in the phytoremediation of Romi stream: A case study of Kaduna refinery and petrochemical company polluted stream. Int J Health Sci Res 2015; 5:492-497.

56. Khan MU, Malik RN, Muhammad S. Human health risk from Heavy metal via food crops consumption with wastewater irrigation practices in Pakistan. Chemosphere 2013; 93:2230-2238.

57. Embrandiri A, Rupani PF, Shahadat M, Singh RP, Ismail SA, Ibrahim MH, Abd. Kadir MO. The phytoextraction potential of selected vegetable plants from soil amended with oil palm decanter cake. Int J Recycl Org Waste Agricult 2017;6:37-45.

58. ZhuY,YuH, Wang J,Fang W, YuanJ,YangZ. Heavy metalaccumulations of 24 asparagus bean cultivars grown in soil contaminated with $\mathrm{Cd}$ alone and with multiple metals $(\mathrm{Cd}, \mathrm{Pb}$, and $\mathrm{Zn})$. J Agric Food Chem 2007; 55:1045-1052.

59. Abolghassem E, Yulong D, Yinfeng X. Phytoremediation potential of bamboo plant in China. Eco Env \& Cons 2018;24(1):530-539.

60. Nejla H, Nadhira BA, Hassen A, Naceur J. Uptake and Bioaccumulation of Pentachlorophenol by Emergent Wetland Plant Phragmites australis (Common Reed) in Cadmium Co-contaminated Soil. International Journal of Phytoremediation 2015; 17:109-116. 
61. Jeelani N, Wen $\mathrm{Y}$, Lingqian $\mathrm{X}$, Yajun $\mathrm{Q}$, Shuqing A, Leng X. Phytoremediation potential of Acorus calamus in soils cocontaminated with cadmium and polycyclic aromatic hydrocarbons. Scientific Reports 2017; 7:8028.

62. Shen $\mathrm{G}, \mathrm{Cao} \mathrm{L}, \mathrm{Lu}$ Y,Hong J. Influence of phenanthrene on cadmium toxicity to soil enzymes and microbial growth. Environmental Science and Pollution Research 2015; 12:259.

63. Yashim ZI, Agbaji EB, Gimba CE, Idris SO. Phytoextraction of Heavy Metals by Vetiverazizanioides, Cymbopogon citrates and Helianthus annuls. American Journal of Applied Chemistry 2015; 3(1):1-5.1757.

64. Ratul AK, Hassan M, Uddin MK, Sultana MS, Akbor MA, Ahsan MA. Potential health risk of heavy metals accumulation in vegetables irrigated with polluted river water. International Food Research Journal 2018; 25(1):329-338.

65. Ugya AY, Imam TS. The efficiency of Eicchornia crassipes in the phytoremediation of waste water from Kaduna Refinery and petrochemical company. IOSR J Environ Sci Toxicol Food Technol 2015; 9:43-47.

66. Saleh J, Hossein G, Ali S, Faezeh A, Yaaghoob H. Phytoremediation Potential of Tomato for $\mathrm{Cd}$ and Cr Removal from Polluted Soils. International Scholarly and Scientific Research \& Innovation 2017; 11(4).

67. Zalewska M, Nogalska A. Phytoextraction potential of sunflower and white mustard plants in zinc-contaminated soil. Chilean J Agric Res 2014; 74:485-489.

68. Chigbo C, Batty L. Phytoremediation for co-contaminated soils of chromium and benzo[a]pyrene using Zea mays L. Environmental Science \& Pollution Research 2014; 21:3051-3059.

69. Andrianos V, Stoikou V, Tsikrika K, Lamprou D, Stasinos S, Proestos C, Zabetakis I. Carotenoids and Antioxidant Enzymes as Biomarkers of the Impact of Heavy Metals in food Chain. Curr Res Nutr Food Sci $2016 ; 4: 15-24$.
70. Vasiliki S, Vangelis A, Sotiris S, Marios GK, Sofia A, Nikolaos ST, Ioannis Z. Metal Uptake by Sunflower (Helianthus annuus) Irrigated withWater Polluted with Chromium and Nickel. Foods 2017; 6:51

71. Pivić RN, Sebić ABS, Jošić DL. Assessment of soil and plant contamination by select heavy metals along a major European highway. Polish Journal of Environmental Studies 2013;22:1465-1472.

72. Stasinos S, Zabetakis I. The uptake of nickel and chromium from irrigation water by potatoes, carrots and onions. Ecotoxicol. Environ Saf 2013; 91:122-128.

73. Lotfy SM, Mostafa AZ. Phytoremediation of contaminated soil with cobalt and chromium. J Geochem Explor 2014; 144:367-373.

74. Bortey-Sam N, Nakayama SMM, Ikenaka Y, Akoto O, Baidoo E, Yohannes YB, Mizukawa H, Ishizuka M. Human health risks from metals and metalloid via consumption of food animals near gold mines in Tarkwa, Ghana: Estimation of the daily intakes and target hazard quotients (THQs). Ecotoxicol Environ Saf 2015; 111:160-167.

75. Iwegbue CMA. Metal concentrations in selected brands of canned fish in Nigeria: Estimation of dietary intakes and target hazard quotients. Environ Monit Assess 2015; 187:1-15.

76. Stasinos S, Nasopoulou C, Tsikrika C, Zabetakis I. The Bioaccumulation and Physiological Effects of Heavy Metals in Carrots, Onions, and Potatoes and Dietary Implications for $\mathrm{Cr}$ and Ni: A Review. J Food Sci 2014; 79:R765-R780.

77. Ugya AY, Tahir SM, Imam TS. 2016. Emerging Trend in the Remediation of Pollution. First Edition, LambertPublishers.

How to cite this article:

Ugya AY, Ahmad AM, Adamu HI, Giwa SM, Imam TS. Phytoextraction of Heavy Metals and Risk Associated with Vegetables Grown from Soil Irrigated with Refinery Wastewater. J App Biol Biotech. 2019;7(2):14-19. DOI: $10.7324 / J A B B .2019 .70203$ 